\title{
CORRIGENDUM
}

\section{Genome-wide common and rare variant analysis provides novel insights into clozapine-associated neutropenia}

SE Legge, ML Hamshere, S Ripke, AF Pardinas, Jl Goldstein, E Rees, AL Richards, G Leonenko, LF Jorskog, Clozapine-Induced Agranulocytosis Consortium, KD Chambert, DA Collier, G Genovese, I Giegling, P Holmans, A Jonasdottir, G Kirov, SA McCarroll, JH MacCabe, K Mantripragada, JL Moran, BM Neale, H Stefansson, D Rujescu, MJ Daly, PF Sullivan, MJ Owen, MC O'Donovan and JTR Walters

Molecular Psychiatry (2018) 23, 162-163; doi:10.1038/mp.2017.214; published online 24 October 2017

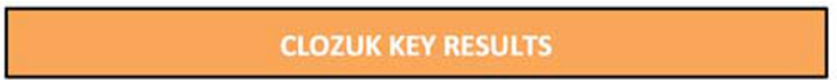

a
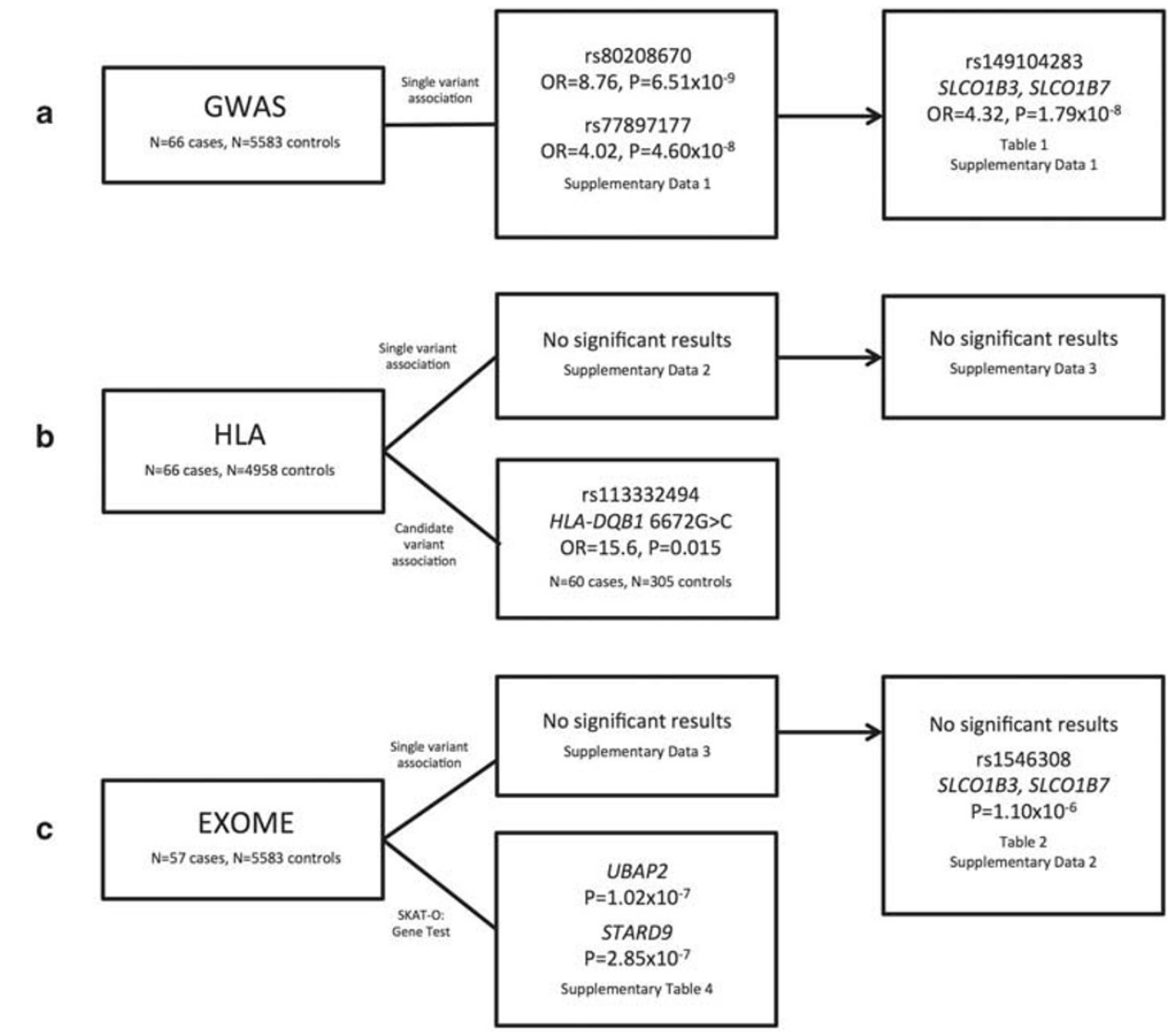

d

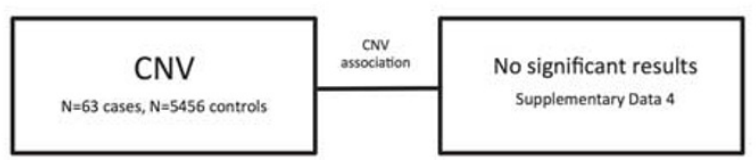


Correction to: Molecular Psychiatry (2017) 22: 1502-1508; advance online publication, 12 July 2017; doi: 10.1038/mp.2016.97

In the first paragraph of the Results section and Figure 1, the authors incorrectly referred to the finding of SNP rs77897117. The correct SNP is rs77897177.

The corrected figure appears in previous page.
This work is licensed under a Creative Commons Attribution 4.0 International License. The images or other third party material in this article are included in the article's Creative Commons license, unless indicated otherwise in the credit line; if the material is not included under the Creative Commons license, users will need to obtain permission from the license holder to reproduce the material. To view a copy of this license, visit http://creativecommons.org/licenses/ by/4.0/

(c) The Author(s) 2018 